\section{Environmental Education: A Place in the Curriculum?}

\author{
RACHEL BOLSTAD
}

\section{Abstract:}

This article examines the place of environmental education/education for sustainable development (EE/ESD) in the school curriculum. Despite international calls for EE/ESD to form the pillar of a re-oriented approach to school curriculum, teaching, and learning, in most schools the principles of EE/ESD are poorly understood, and it occupies a marginal place in curriculum and teaching practice. This article considers the "place" of EE/ESD in the New Zealand curriculum, and the potential to align EE/ESD with a "place-based" education (PBE) approach in New Zealand schools. Current directions from the New Zealand Curriculum Project may create new possibilities for this to occur.

$\mathrm{E}$ vironmental education (EE), also known as education for sustainable development (ESD), is a relatively new contender for a place in school curriculum. This year, 2005, marks the beginning of a UN decade of education for sustainable development. Most nations now acknowledge the need for EE/ESD to be a part of everyone's education, and the 1990s saw the development of policies and strategies to support the growth of EE/ESD in formal and non-formal education. A handful of schools in New Zealand and in other countries have begun to re-orient themselves to become "environmental" or "environmentally sustainable" schools. ${ }^{1}$ Yet for the majority of schools in New Zealand and around the world, the principles and practices of EE/ESD are poorly understood, and environmental education occupies, at best, a marginal place in mainstream school curriculum and teaching practice.

A double meaning is intended by the title of this article, "Environmental education: a place in the curriculum?" The first meaning concerns the place (or more often, lack of place) of environmental education in school curriculum. This article discusses reasons for environmental education's tenuous-to-non-existent status in the curriculum of many schools, despite repeated international calls for EE/ESD not only to have a place in the curriculum, but to form the pillar of a completely re-oriented approach to school curriculum, teaching, and learning. The second meaning concerns the concept of "place" itself in the curriculum. Drawing from recent literature on ecological education and indigenous education (Gruenewald, 2003; Penetito, 2004), I explore the idea that a "place-based" educational approach (PBE) represents a potent new direction for bringing EE/ESD to the forefront of curriculum and teaching practice in New Zealand schools.

\section{A Place for Environmental Education in the Curriculum}

Familiar subjects like mathematics, science and English have been taught in schools for so long that their place in the curriculum is rarely questioned, and they could be considered to have become "cultural institutions" (Gough \& Scott, 2001; Reid, 1990) in today's schools. The unquestioned status of these subjects in the curriculum signifies an equally unquestioned belief that students will develop and use the skills, knowledge, attitudes, and values associated with these disciplines as they journey through their school careers, and in their lives beyond school. But without critical scrutiny, our taken-for-granted assumptions about schooling and curricula, "can divert our attention from important questions we might be asking about the present functions of curricula and how new functions might be envisaged" (Reid, 1990, p. 203).

Given the rapid pace by which social and cultural priorities, and technological and social environments change, the institutional categories we call "curricula" are surprisingly resistant to redesign. They are particularly resistant to the introduction of new kinds of education that do not conform either to a traditional view of curriculum, or to the implicit ideas and values that underpin mainstream schooling practice. Gough and Scott (2001) use the analogy of a skier travelling downhill with a heavy pack. Like "institutionalised" ideas about curriculum, the inertial effect of the pack is nearly impossible for the skier to overcome. "All attempts to turn, however imaginative, necessary, or skilfully executed, will end in failure. The pack will continue in the direction it was going and take you with it" (Gough \& Scott, 2001).

Global thinking about environmental and sustainability education has changed substantially over the last few decades, yet, like the skier trying to change direction, the impact of this thinking on mainstream 
school curriculum and teaching practice has been minimal. Although there have always been examples of teachers practising environmental education in their own schools and classrooms, most of the ideas and concepts that underpin environmental education have developed outside the school education system, and are closely tied to international social, political, and environmental developments during the last fifty years. Gough (1997) describes environmental education as a form of "adjectival education" - areas which have often been championed most strongly by people and groups outside, rather than inside, the mainstream school system. Other examples might include peace education (Sellers, 2003), values education, or citizenship education (Westheimer \& Kahne, 2004). The "extra-curricular" origins of these movements, and their frequently political or contentious underpinnings, help to explain why they often fail to gain status in schools.

In the sections that follow, I take this idea further to consider three specific reasons why environmental education/education for sustainable development has had difficulty establishing a place within the practice of most schools. First, many teachers are not really familiar with the underlying principles of EE/ESD. Secondly, the pedagogies associated with EE/ESD diverge from the normal kinds of teaching and learning practices in many schools. Thirdly, even when there is a will to teach EE/ESD, ways to do this within the current New Zealand curriculum are sometimes perceived as being limited. While significant, these challenges are not unsurmountable. Below, I suggest ways to address each of them, so as to support further development of environmental education in New Zealand schools.

\section{The "Extra-curricular" Origins of the Environmental Education Movement}

The environmental education movement emerged during the 1960 s and 1970s from growing concerns about global environmental degradation. Since all humans were seen as contributing in some degree to environmental problems, it followed that everyone would need to participate in finding solutions and changing their current behaviours and practices with respect to the environment. Education was seen as critical to promoting long-term changes in the way that people used and cared for their environment. During the 1970s, the United Nations Educational, Scientific and Cultural Organisation (UNESCO) sponsored a number of international conferences and special programmes which aimed to promote environmental education. These efforts culminated in the world's first Intergovernmental Conference on Environmental Education in Tbilisi (USSR) in 1977 (UNESCO, 1978), and the Tbilisi declaration, which established a framework, principles, and guidelines for environmental education. The Tbilisi declaration maintained that environmental education should be provided for people of all ages, at all levels, and in both formal and non-formal education. It presented a vision of environmental education as lifelong, holistic, and interdisciplinary, and emphasised the interdependencies between humans and the environment. The Tbilisi declaration portrayed environmental education as both forward-looking and outward-looking, suggesting that it could bring about significant changes to existing methods and practices of education.

Environmental education must look outward to the community. It should involve the individual in an active problem-solving process within the context of specific realities, and it should encourage initiative, a sense of responsibility and commitment to build a better tomorrow. By its very nature, environmental education can make $a$ powerful contribution to the renovation of the educational process. (UNESCO, 1978, p. 24) [emphasis added]

In spite of these optimistic goals, the educational process in schools throughout the world remained largely unchanged by the Tbilisi declaration. While there was certainly an awareness of environmental problems, it was clear that this awareness did not translate into a concerted shift towards a community-focussed, action-oriented approach to teaching and learning in schools. However, the 1970s and 1980s were an important period of environmental consciousness-raising, and students at school during this time would certainly have been exposed to new ideas about environmental and conservation matters.

\section{From "Environmental Education" to "Education for Sustainability"}

During the 1980s and 1990s, as EE continued to sit at the margins of the curricula in most schools, the attentions of UNESCO and other international drivers of environmental education policy broadened to further examine the relationships between environmental concerns, poverty, economic and social development, and the well-being of human communities. In 1987 the World Commission on Environment and Development (UNCED) defined the term "sustainable development". This led to a redirection of the international agenda for 
environmental education. The most significant landmark for this was the 1992 Earth Summit $^{2}$ in Rio de Janeiro, where Agenda $21^{3}$ (United Nations Commission on Environment and Development, 1992) was developed and adopted. Building on the recommendations of the Tbilisi Declaration and subsequent summits and documents, Agenda 21 called for the re-orientation of environmental education towards "education for sustainable development".

Agenda 21 was a powerful stimulus for the development and implementation of environmental education policy in many countries, including New Zealand, as governments sought to respond to their Earth Summit obligations. Agenda 21 proposed that governments, in co-operation with all sectors of society, prepare strategies aimed at integrating environment and development issues into all levels of education. It also proposed that every school be assisted to design environmental activity work plans, with the participation of students and staff (UNESCO, 1992). Along with many other countries, New Zealand developed policies during the 1990s that seemed to acknowledge a place for environmental education across all sectors. The Ministry for the Environment developed Learning to Care, a national strategy for environmental education (Ministry for the Environment, 1998), and the Ministry of Education published the Guidelines for Environmental Education in New Zealand Schools (Ministry of Education, 1999a).

After Agenda 21 the term "environmental education" was increasingly supplanted by terms such as "education for sustainable development" (ESD), "education for a sustainable future", or "education for sustainability". These new terms reflected a broadening of concern away from an educational approach that largely focused on environmental and conservation issues, to one which integrates concerns for social, political and economic development, and addresses education for long term ecological and social sustainability (Tilbury, 1995). In New Zealand, the language of "sustainability" has taken root in many sectors (Parliamentary Commissioner for the Environment, 2004; Statistics New Zealand, 2002). However, the term "environmental education" continues to predominate in the school sector. Some stakeholders in the EE/ESD community argue that the language of "environmental education" may be unhelpful for promoting the development of education for sustainability (Parliamentary Commissioner for the Environment, 2004). The Commissioner's report notes that it is not the words per se that are important, but how they are used and what they mean to people (p. 39). While some people use the terms interchangeably, there is also evidence that older, more nature-and-conservation-focussed conceptions of environmental education in schools have not been superseded by the newer, more broadly-based concepts of education for sustainability.

Indeed, the "new" ideas that underpin the reconceptualised environmental education of the 1990s have not been part of teachers' own education, experience, and training. Teachers may well have learned about the environment, conservation, pollution, or waste management at school. Depending on when and where they went to university, and what they studied, they may have learned about environmental science, ecology, the management of natural resources, and so on. However, their own education may not have exposed them to a view that situates environmental sustainability issues within an integrated framework of social, economic, political, and ecological concerns. Because these interlocking threads of environmental sustainability are often fragmented across different courses and disciplines in universities (Parliamentary Commissioner for the Environment, 2004), even many younger teachers may not have learned about environmental sustainability in this way.

Even if teachers come to understand the principles of environmental sustainability, this does not mean that they will necessarily know how to teach it. In the past, pre-service and in-service environmental education opportunities for New Zealand teachers were often focussed on the biophysical dimensions of the environment. Only one or two colleges of education offered courses with a more integrated "sustainability" focus. However, by the late 1990s, professional development programmes associated with the Guidelines were introducing larger numbers of (mostly primary) teachers to the principles of environmental sustainability. Other opportunities for sustainability-focussed teacher environmental education have gradually expanded, with several teacher education institutions now offering undergraduate and post-graduate teacher education courses.

What Does "Learning for A Sustainable Future" Mean for Schools?

Tilbury (1995) defines learning for a sustainable future as being:

- Relevant: because it seeks to interest and involve students in environmental issues that are a real and immediate global concern.

- Holistic: first, because it is concerned with how people interact with 
their total environment, and second, because it addresses environmental problems holistically through the curriculum.

- Values-orientated: because values are central in determining peoples' decisions and actions towards the environment.

- Issues-based and action-orientated: because it engages learners in a process of identifying and investigating issues, seeking solutions, and carrying out actions towards resolution of these issues.

- Critical education: because learners need to develop critical thinking skills to understand the complexity of environmental problems and solutions, and the ability to challenge bias, support rational decision-making, and examine prospects and solutions for change.

These features make learning for a sustainable future a challenging area for schools. Contemporary literature on environmental education in schools often describes environmental education in terms of three dimensions: education "in" the environment, education "about" the environment, and education "for" the environment. ${ }^{4}$ Genuine environmental education is considered to occur only when education "for" the environment is the paramount concern (Fien \& Greenall Gough, 1996). Research suggests, however, that most of what is labelled environmental education in schools comprises education "in" and "about" the environment. Education "for" the environment suggests that it is not enough simply for students to learn about the environment or the causes and consequences of environmental problems. Indeed, research has found that teaching students about the causes and severity of the world's environmental problems can leave them feeling hopeless and despairing about the future (Hicks \& Bord, 2001), and can actually discourage students from taking action, because they feel they cannot make a difference. Furthermore, an overemphasis on undesirable future environmental scenarios may mute discussion about current environmental and sustainability issues and the social, political, and economic relationships that support or sustain them (Gruenewald, 2004)

The old environmental adage "think globally, act locally", takes on a new significance here. While it is certainly important for students to understand the "big-picture" issues of global environmental sustainability, they have little chance of directly influencing change at this level. One can argue that it is not schoolchildren's responsibility to fix an entire world, damaged by the additive and collective actions of the whole human species. Instead, school environmental education must bring its immediate focus into a sphere in which students can, or at least should have an influence: the school and the wider communities with which its students interact.

Using their own communities as a context to educate students "for" the environment helps learners to recognise that environmental problems are structurally anchored in society, and therefore have to be understood as community issues in which conflicting interests will arise at several levels: individual, social, and structural. Thus, environmental education should help students to identify, expose, and analyse all three levels of conflicting interest, and how they affect the environment, so that they might take actions which address these root causes of environmental concerns (Breiting \& Mogensen, 1999). Framed in this way, the purpose for teaching environmental education in schools is not for students simply to learn how to address "symptoms" of environmental problems, but to learn how to be active participants in a society that is capable of achieving sustainable solutions to them. In doing so, students should have the opportunity to develop skills and knowledge, such as how to identify and investigate a problem, seek out information and resources, approach people in the community for advice or support, or take into account different people's needs and perspectives on an issue relating to the environment. The Royal Danish School of Educational Studies refers to this process as the development of learners' "action competence" (Breiting \& Mogensen, 1999; Jensen \& Schnack, 1997). The point is for students to become competent and conscious participants both in current and future actions that contribute to the solution or avoidance of environmental problems.

Environmental education of the kind described above presents opportunities for student participation in school decision-making, something which is increasingly seen as valuable for New Zealand schools to foster (Education Review Office, 2003). It also calls for the use of authentic contexts for teaching and learning and offers new possibilities for curriculum integration. By fostering students' engagement with real issues in their own communities, it presents opportunities for them to learn how to genuinely "make a difference". However, international and New Zealand research (Bolstad, Cowie, \& Eames, 2004) suggests that most students are unlikely to have these kinds of environmental education learning experiences at school. Why? At the practical level, environmental education seems to butt up against some of the embedded structures of schools, including the constraints of the school timetables, the division of the curriculum into separate 
subjects, the demands of assessment, and so on. At a deeper level, environmental education can also be seen as transgressing what is viewed as normal or acceptable for students to be doing at school. Some have argued that the "transformative" goals of environmental education fundamentally conflict with the concepts that underpin conventional schooling, where the purpose of education is to more or less reproduce current societal norms and associated environmental and social injustices (Bowers, 2002; Sterling, 2001; Stevenson, 1987).

The next section draws from our recent research on environmental education practice in New Zealand schools (Bolstad, Cowie, et al., 2004) to illustrate how both kinds of challenges can hinder the development of school-based EE/ESD.

\section{Environmental Education and the New Zealand Curriculum}

In the curriculum framework, environmental education is positioned as a non-mandatory learning area which is to be integrated across the existing seven essential learning areas. ${ }^{5}$ The Guidelines for Environmental Education in New Zealand Schools (Ministry of Education, 1999a) outline the key aims and principles of environmental education (see Table 1 on p. 226) and point out how these link to learning aims and objectives in other curriculum areas. For example, in social studies "students will understand people's interactions with places and the environment ... and people's allocation and management of resources" (Ministry of Education, 1997, p. 8). In health and physical education "students will understand the interdependence between people and their surroundings and use this understanding to help create healthy environments" (Ministry of Education, 1999b, p. 9). In science, "students will ... investigate how people's decisions and activities change planet Earth's physical environment, and develop a responsibility for the guardianship of planet Earth and its resources" (Ministry of Education, 1993a, p. 106).

Although environmental education is not subject to the same levels of funding, professional development, or assessment and reporting requirements as the other seven mandatory curriculum learning areas, in the last few years central and local government agencies have provided funding and support for teachers and schools to develop their own environmental education programmes. Following the publication of the Guidelines, an extensive programme of professional development was instituted (Arcus, 2004). Regional consortia comprising educators from colleges of education, local government and some non-governmental organisations worked with teachers in workshops and in-school visits to assist them to develop familiarity with the Guidelines. A smaller number of primary and secondary schools and kura kaupapa Māori were selected to become pilot schools, entering into agreements to more fully implement aspects of the Guidelines in their curriculum, landscaping, and property management. In 2003, Ministry of Education funding was allocated to employ 11 full time equivalent environmental education regional coordinators to assist schools to access the many environmental education resources and programmes available through local and regional councils, environmental and conservation agencies, and non-governmental organisations (NGOs).

This approach of enabling rather than requiring schools to develop environmental education in their curriculum programmes is consistent with the intentions of the New Zealand Curriculum Framework (Ministry of Education, 1993b), which clearly distinguishes between two levels of "curriculum". Curriculum with a capital "C" denotes the New Zealand Curriculum - the set of national curriculum statements that define the learning principles and achievement aims and objectives which all New Zealand schools are required to follow. Curriculum with a lower-case " $c$ " denotes the school curriculum - the ways in which a school puts into practice the policies set out in the national curriculum statements. The Framework indicates that the school curriculum must be

... sufficiently flexible to respond to each student's learning needs, to new understanding of the different ways in which people learn, to changing social and economic conditions, to national needs, and to the requirements and expectations of local communities. (Ministry of Education, 1993b, p. 6)

Taken together, these statements in the New Zealand Curriculum Framework, the development of the Guidelines for Environmental Education in New Zealand Schools, and support from the Ministry of Education and other agencies for environmental education programmes and professional development, suggest a legitimate space is available for environmental education in New Zealand schools. However, our research found that schools had varied success in bringing environmental education securely into their curriculum and teaching practice (Bolstad, Cowie, et al., 2004). As part of the study we surveyed 367 staff from 193 New Zealand primary, intermediate, and secondary schools to identify some of the key issues and challenges involved in school-based environmental education. ${ }^{6}$ The survey found a high degree 
of enthusiasm about the value of including environmental education in the school curriculum, and the benefits it held for students, the school, and the community. However, some teachers and school leaders felt that the lesser status and visibility of environmental education in the national curriculum created significant challenges. The evolution of practice of environmental education in many schools appeared to be of an ad hoc nature, driven by one or more enthusiastic teachers, who were acting with or without knowledge of the Guidelines. Good school leadership was seen as critical in building environmental education programmes in schools, and some teachers noted their frustration with the lack of support from their colleagues and leaders. Some environmental education teachers wondered about the sustainability of their programmes, should they run out of energy or leave the school. Other survey respondents saw environmental education as yet another curriculum initiative to deal with. For example, one deputy principal wrote: "To be blunt, environmental education appears to me to be yet another add-on to an already crowded curriculum."

If environmental education is to secure a place in schools, it will be important to counteract the view that it is something additional to the existing curriculum. Instead, schools will need sufficient guidance and support to develop a clear understanding of why they should teach environmental education, and in particular, how it can contribute to their overall learning aims, and vice versa (Scott \& Reid, 1998). However, it is not enough just to want to bring environmental education into the school curriculum. Schools also need to find ways to do this. To understand the factors that help or hinder this process, we should look to New Zealand schools that have already given environmental education a place in the school curriculum.

\section{Features of Environmental Education Practice in New Zealand Schools}

There is another old adage: "where there's a will, there's a way". Assuming that teachers' familiarity with the principles and pedagogies of EE/ESD creates a will to teach it in schools, are there obvious and achievable ways for this to happen? Further, what ideas do New Zealand teachers' currently hold about environmental education, and how are these enacted in environmental education practice?

Our research (Cowie et al., 2004) suggested variations in the extent to which New Zealand teachers' understandings of environmental education were consistent with those outlined in the Guidelines and other EE/ESD literature. The survey asked respondents to describe what they understood the term "environmental education" to mean, and their purposes for teaching it. Responses were analysed in terms of the 5 aims, 3 dimensions, and 4 key concepts of environmental education outlined in the Guidelines for Environmental Education in New Zealand Schools (Ministry of Education, 1999a) (See Table 1). Teachers' responses were dominated by a concern with "education about the environment".

Table 1 Key aims, concepts, and dimensions of environmental education identified in the Guidelines

\begin{tabular}{lll}
\hline Five Aims & $\begin{array}{l}\text { Four Key } \\
\text { Concepts }\end{array}$ & $\begin{array}{l}\text { Three Key } \\
\text { Dimensions }\end{array}$ \\
\hline $\begin{array}{l}\text { Aim 1: students to develop awareness } \\
\text { and sensitivity to the environment } \\
\text { and related issues. }\end{array}$ & Interdependence & $\begin{array}{l}\text { Education in the } \\
\text { environment }\end{array}$ \\
$\begin{array}{l}\text { Aim 2: students to develop knowledge } \\
\text { and understanding of the environment } \\
\text { and the impact of people on it. }\end{array}$ & Sustainability & $\begin{array}{l}\text { Education about } \\
\text { the environment }\end{array}$ \\
$\begin{array}{l}\text { Aim 3: students to develop attitudes and } \\
\text { values that reflect feelings of concern }\end{array}$ & Biodiversity & $\begin{array}{l}\text { Education for the } \\
\text { environment }\end{array}$
\end{tabular}
for the environment.

Aim 4: students to develop skills involved in identifying, investigating, social respons-

and problem solving associated with ibility for action environmental issues.

Aim 5: students to develop a sense of responsibility through participation and action as individuals, or members of groups, whānau, or iwi, in addressing environmental issues.

Over two-thirds of respondents mentioned the development of student knowledge, understanding, and awareness of the environment and environmental issues (Aims 1 and 2). One-third of respondents described the development of student values and attitudes towards the environment (Aim 3). Around 20 percent listed student actions for the environment in their definition of environmental education (Aim 5), 
although this rose to 33 percent when respondents outlined their purposes for teaching environmental education.

The survey specifically asked respondents to describe an environmental education topic or unit they had taught, and how (if at all) this topic had involved students taking action "for" the environment. A variety of student actions were reported, including cleaning up and recycling litter, gardening, planting native trees and plants in the school and along waterways, and writing letters to businesses, community groups, and government departments. Some topics such as resource management and global issues were less likely to yield reports of student actions, but were said to contribute to students identifying and planning for action, and changing student attitudes towards environmental issues. Only twelve percent of respondents specifically indicated that student decision-making and/or student-directed action was involved in their environmental education unit.

We also visited and case-studied environmental education practice in eight different schools, including two primary schools, two area schools, one intermediate, two secondary schools, and a kura kaupapa Māori (Bolstad, Cowie, et al., 2004). Several of these schools were committed tolarge-scale environmental action projects, illustrating some rich examples of student leadership and decision-making in environmental education activities. Some students involved in these projects described immense pride in their undertakings and felt they had learned more through involvement in these activities than they might have in a conventional classroom teaching approach. They also talked about learning how to actually "do something". Examples were: how to cultivate a garden, a compost system, or a worm farm; how to develop landscaping plans; how to approach businesses, councils, or Boards of Trustees with a funding proposal; how to liaise with the media, or find ways to communicate an environmental message to the wider community (Bolstad, Eames, Cowie, Edwards, \& Rogers, 2004). Most of the case study schools were moving towards formalising their commitment to environmental education through its inclusion in school policy and planning documents. Challenges and issues arising for staff in the case study schools paralleled those in the total sample of 367. They included: dependence on key people to provide energy and expertise in environmental education; the amount of time and energy required to sustain environmental education projects; getting other staff and/or Board of Trustees "on board" with environmental education; having sufficient resources or ideas for environmental education teaching and learning; ensuring the sustainability of environmental education by developing school structures and policies to support it; planning environmental education projects that could be sustained for successive cohorts of students; and having time to establish and maintain links with the community and environmental agencies.

For secondary schools in particular, finding acceptance for environmental education within or across established subject areas is often a challenge. An illustrative example from our case studies was a Year 12 Level 2 NCEA environmental education course called "Sustainable Futures", developed and offered at Christchurch Girls" High School for the first time in 2003 with 12 enrolled students. The course was initiated and implemented by a biology teacher and a geography teacher who shared teaching of the course. Both teachers felt there were "really important [things], that kids should be talking about and getting involved in" which weren't possible within the existing subjects offered in the school:

... like actually having time to go and work with a community organisation ... you just don't get the time [in existing science and geography courses] to allow students to go out there and work with another group. (Geography teacher, cited in Bolstad, Eames, et al., 2004, p. 98)

The teaching approach in "Sustainable Futures" distinguished it from most other Year 12 courses at the school. Students were expected to be more involved in deciding what they were going to do and how they were going to do it. Students were provided with booklets of readings each term, compiled by the teachers from a wide variety of sources to reflect the main themes of the course. However, the two teachers viewed themselves as co-learners with their students, in the sense that much of the course content was constructed by the teachers and students during the year. The principal and senior management teams were receptive to the teachers' ideas about bringing environmental education into the school curriculum. However, one teacher described the first 12 "Sustainable Futures" students as the "brave ones", because they were willing to do the new course in spite of some of the negative comments that had been directed towards the course from other staff. The students expressed frustration that some other subject teachers and some of their peers didn't seem to know what the "Sustainable Futures" course was, or didn't see it as a "serious" subject. 
I remember my English teacher saying last year "Oh, and there's Sustainable Futures, but I don't know why anyone would do that, is anyone in this class doing that?" And I was the only one, and I thought, well I'm not putting up my damn hand! (Sustainable Futures student, cited in Bolstad, Eames, et al., 2004, p. 105)

\section{Place-based Education: A Way Forward?}

Examples like the ones above suggest that if EE/ESD is to flourish successfully in all schools, some institutionalised ideas about schooling and curriculum will need to be relinquished and some new ideas will need to be embraced. One idea which may have powerful impact for New Zealand schools is the notion of place-based or "place-conscious" education (Gruenewald, 2003; Penetito, 2004). Gruenewald argues that the current education system "often distracts our attention from, and distorts our response to, the actual contexts of our own lives (places)" (p. 621). Penetito elegantly captures this notion with three fundamental questions (or "spatial metaphors") that most school education seems to neglect, but which would underpin a place-based education (PBE) approach. These questions are: "Who am I?" "Where am I?" and "What is this place and how do we fit into it?" He argues that a PBE approach "encapsulates in some essential way every educational initiative that Māori have supported from before the establishment of the Native Schools Act of 1867 right through to the current kaupapa Māori agenda" (p. 10). While Māori and indigenous peoples may have an existing affinity to PBE practices, Penetito believes that a PBE approach is educationally and culturally beneficial for all students. He suggests that a basic objective of PBE:

... is to develop in learners a love of their environment, of the place where they are living, of its social history, of the bio-diversity that exists there, and of the way in which people have responded and continue to respond to the natural and social environments. (p. 11)

Place-conscious education suggests that every school's role is to cultivate the kind of people who will sustain, transform, or create the kinds of "places" we want our world to comprise, at the local, regional, national, and global level. This requires us to think of school learners as current and future "place-makers". Supporting students to participate meaningfully in the process of place-making requires their school learning to have visible and meaningful connections to local, as well as national and international, contexts, knowledges, and resources.
Henderson and Tilbury consider that this represents a redefinition of the role of schools, and their relationship with the community.

The focus has shifted beyond "what to teach students" and "how they are behaving" to seeing schools as a focal point where children, adults, and the community interact and learn together. (2004, p. 8 )

If schools were to adopt PBE as a central concept, environmental education would emerge as an obvious context for students to practice being "place-conscious" and "place-makers" in their own school and communities.

New Zealand and international research suggests that a whole-school commitment to education for sustainability is fundamental for schools to succeed at becoming "place-conscious" or "sustainable" schools (Henderson and Tilbury, 2004). Two examples, one from New Zealand, and one from overseas, illustrate the essential principles of a whole-school approach to sustainability. The Enviroschools programme began with three Hamilton schools in 1993, supported by a taskforce including teachers, the Department of Conservation, Hamilton City Council, Environment Waikato, and the University of Waikato. The programme became available nation-wide for the first time in 2002 (Mardon \& Ritchie, 2002). A similar initiative in Austria, the "ecologisation of schools" (ECOLOG) project, began in 1996 with 22 primary schools. The principle behind these whole-school approaches is that "children learn informally through the messages and meanings hidden within the physical surroundings, operational practices and organisational principles of a school" (Hamilton City Council, 2001, p. 7). In these "eco-school" models, three levels of change are required to achieve a sustainable school environment (Posch, 1999, p. 342). At the pedagogical level, schools aim to create stimulating and meaningful learning experiences and involve pupils in ecological ways of thinking, acting and feeling in school, in their family, and in the community. At the social/organisational level, schools aim to build and cultivate a culture of communication, respect, and shared decision-making. At the technical/economic level, schools aim for ecologically sound, economic, and sustainable use of resources. The eco-school model indicates that learning is, and should be, inextricably connected with the cultivation of the physical, social, cultural, and spiritual environment of the school and its community. While this may be a challenging way of thinking for some schools, it has strong resonance with other models of education, including kura kaupapa Māori (Mataira, 1997), and some models for 
peace education (Sellers, 2003) and rural education (The Rural School and Community Trust, 2002). These approaches require schools to recognise and critically examine the "hidden curriculum" - that is, the infrastructure which either supports or works against the intentions of education for sustainability. This contrasts with conventional curriculum development processes in schools, where curriculum decisions are largely driven by national curriculum statements and enshrined subject/disciplinary knowledge divisions (science, social studies, etc.). However, directions emerging from the current New Zealand Curriculum/Marautanga Project ${ }^{7}$ provide cause for optimism (Thomson, 2004). This includes a focus on clarifying and reducing the number of achievement objectives and reducing pressures on schools to feel they have to "cover" all the learning objectives in the curriculum. A renewal of schools' license to take control and responsibility for school-based curriculum development (Bolstad, 2004) would open the way for schools to embrace place-based education and education for sustainability as pillars around which to build their curriculum. Then, education for sustainability would not only have a place in school curriculum, it would also help to bring "place" into the school curriculum.

\section{Notes}

1. Examples in New Zealand include Enviroschools, and a number of schools involved in Ministry of Education environmental education professional development programmes.

2. The United Nations Conference on Environment and Development

3. Agenda 21 is a comprehensive plan of action to be taken globally, nationally and locally by organisations of the United Nations, governments, and major groups in every area in which humans impact on the environment.

4. Sellers (2003) uses this same construct to describe three facets of peace education: education in peace, about peace, and for peace.

5. Science, social studies, mathematics, English, technology, health and physical education, and the arts.

6. Because the research aimed to investigate characteristics of environmental education practice, the sample was purposively selected to only include schools which we believed to feature environmental education in some form in their teaching programmes (Cowie et al.,2004).
7. The New Zealand Curriculum/Te Marautanga o Aotearoa Project involves a wide-ranging process to engage teachers, principals, students, lecturers, and others in revitalising the New Zealand curriculum. The goals of the project, which runs from 2004 to 2007, are to: clarify and refine outcomes; focus on quality teaching; strengthen school ownership of curriculum; and support communication and strengthen partnerships with parents/whānau and communities.

\section{References}

Arcus, C. (2004). Policy, research, and capacity building for educational innovation for sustainable development. Report prepared for NIER/UNESCO/APEID. Wellington.

Bolstad, R. (2004). School-based curriculum development: Principles, processes, and practices. Wellington: New Zealand Council for Educational Research.

Bolstad, R., Cowie, B., \& Eames, C. (2004). Environmentaleducation in New Zealand schools: research into current practice and future possibilities. Volume 1: Summary of the research findings. Wellington: Ministry of Education.

Bolstad, R., Eames, C., Cowie, B., Edwards, R., \& Rogers, N. (2004). Environmental education in New Zealand schools: Research into current practice and future possibilities. Volume 4: Case studies of environmental education practice in eight schools and kura kaupapa Māori. Wellington: Ministry of Education.

Bowers, C. A. (2002). Toward an eco-justice pedagogy. Environmental Education Research, 8(1), 21-34.

Breiting, S., \& Mogensen, F. (1999). Action competence and environmental education. Cambridge Journal of Education, 29(3), 349-353.

Cowie, B., Eames, C., Harlow, A., Bolstad, R., with, Barker, M., Keown, P., Edwards, R., \& Coll, R. (2004). Environmental education in New Zealand schools: Research into current practice and future possibilities. Volume 3: A critical stocktake of the characteristics of effective practice in environmental education in New Zealand schools and kura kaupapa Māori. Wellington: Ministry of Education.

Education Review Office. (2003). Student participation in school decision-making. Wellington: ERO. 
Fien, J., \& Greenall Gough, A. (1996). Environmental education. In R. Gilbert (Ed.), Studying society and environment-a handbook for teachers (pp. 200-216). Melbourne: Macmillan.

Gough, A. (1997). Education and the environment: Policy, trends and the problems of marginalisations. Melbourne: Australian Council for Educational Research.

Gough, S., \& Scott, W. (2001). Curriculum development and sustainable development: Practices, institutions and literacies. Educational Philosophy and Theory, 33(2), 137-152.

Gruenewald, D. (2003). Foundations of place: A multidisciplinary framework for place-conscious education. American Educational Research Journal, 40(3), 619-654.

Gruenewald, D. (2004). A Foucauldian analysis of environmental education: Toward the socioecological challenge of the Earth Charter. Curriculum Inquiry, 34(1), 71-107.

Hamilton City Council. (2001). Enviroschools handbook. Hamilton: Hamilton City Council.

Henderson, K., \& Tilbury, D. (2004). Whole-school approaches to sustainability: An international review of sustainable school programs. Report prepared by the Australian Research Institute in Education for Sustainability (ARIES) for the Department of the Environment and Heritage, Australian Government.

Hicks, D., \& Bord, A. (2001). Learning about global issues: Why most educators only make things worse. Environmental Education Research, 7(4), 413-425.

Jensen, B. B., \& Schnack, K. (1997). The action competence approach in environmental education. Environmental Education Research, 3(2), 163-179.

Mardon, H., \& Ritchie, H. (2002). Enviroschools programme evaluation report. Wellington: Enviroschools.

Mataira, K. (1997). Te aho mātua o nga kura kaupapa Māori. An interpretation of the Māori language document for the Minister of Education, Wyatt Creech.

Ministry for the Environment. (1998). Learning to care for our environment: A national strategy for environmental education. Wellington: Ministry for the Environment.
Ministry of Education. (1993a). Science in the New Zealand Curriculum. Wellington: Learning Media.

Ministry of Education. (1993b). The New Zealand Curriculum Framework. Wellington: Ministry of Education.

Ministry of Education. (1997). Social studies in the New Zealand Curriculum. Wellington: Learning Media.

Ministry of Education. (1999a). Guidelines for environmental education in New Zealand schools. Wellington: Learning Media.

Ministry of Education. (1999b). Health and physical education in the New Zealand curriculum. Wellington: Learning Media.

Parliamentary Commissioner for the Environment. (2004). See change: Learning and education for sustainability. Wellington: Parliamentary Commissioner for the Environment.

Penetito, W. (2004, November). Theorising a "place-based" education. Paper presented at the the NZARE Conference, Wellington.

Posch, P. (1999). The ecologisation of schools and its implications for educational policy. Cambridge Journal of Education, 29(3), 341-348.

Reid, W. (1990). Strange curricula: Origins and development of the institutional categories of schooling. Journal of Curriculum Studies, 22(3), 203-216.

Scott, W., \& Reid, A. (1998). The revisioning of environmental education: A critical analysis of recent policy shifts in England and Wales. Educational Review, 50(3), 213-223.

Sellers, M. (2004). Peaceful perspectives: Peace education, educating for peace. New Zealand Annual Review of Education, 13, 225-248.

Statistics New Zealand. (2002). Monitoring progress towards a sustainable New Zealand: An experimental reportand analysis. Wellington: Statistics New Zealand.

Sterling, S. (2001). Sustainable education: Re-visioning learning and change. Bristol: Green Books.

Stevenson, R. (1987). Schooling and environmental education: Contradictions in purpose and practice. In I. Robottom (Ed.), Environmental education: Practice and possibility (pp. 69-82). Geelong: Deakin University Press.

The Rural School and Community Trust. (2002). Principles of place-based education. Rural Roots, 3(4). Available at $<$ www.ruraledu.org/roots/rrtext/rr3.4.html\# principles $>$ 
Thomson, R. (2004). Putting the big issues first. New Zealand Education Gazette, 83(17), 9.

Tilbury, D. (1995). Environmental education for sustainability: Defining the new focus of environmental education in the 1990s. Environmental Education Research, 1(2), 195-212.

United Nations Commission on Environment and Development (UNCED). (1992). Agenda 21. Paris: United Nations.

UNESCO. (1978). Final Report: Intergovernmental Conference on Environmental Education, Tbilisi (USSR), October 14-26, 1977. Paris: UNESCO.

UNESCO. (1992). Report of the United Nations Conference on Environment and Development. Chapter 36 "Promoting education, public awareness and training". Rio de Janeiro, June 3-14. UNESCO.

Westheimer, J., \& Kahne, J. (2004). What kind of citizen? The politics of educating for democracy. American Educational Research Journal, 41(2), 237-269.

\section{The author}

Rachel Bolstad is a researcher at the New Zealand Council for Educational Research. She has been involved in research on environmental education in New Zealand schools, and recently wrote a background paper on school-based curriculum development for the leaders of the New Zealand Curriculum/Marautanga Project. 